\title{
ECOHYDROLOGICAL MONITORING OF THE RIVER HABITAT QUALITY
}

\begin{abstract}
M. M a t o u šk o vá : Ecohydrological monitoring of the river habitat quality. - Geografie Sborník ČGS, 109, 2, pp. 105-116 (2004). - Complex ecohydrological methods are of principal significance when evaluating the state of water ecosystems and they give also decisive information for their restoration. New approaches in the evaluation allow a broader view at the water ecosystem. The ecohydrological state of a stream is determined by a set of hydromorphological characteristics of the river channel, of its runoff, by hydrochemical and hydrobiological condition of water, by the character of bank and riparian belts and transformation of the floodplain. The new European Water Framework Directive (2000/60/EC) underlines the significance of ecohydrological methods. In the paper is represented a method of ecomorphological evaluation of streams habitat quality and its application on the model study area of the Rakovnický Brook.
\end{abstract}

KEY WORDS: ecohydrological monitoring - river habitat - river training hydromorphology - vegetation belt - riparian zone - water basin.

\section{Introduction}

From the beginning of the eighties, efforts have come up to develop an objective and complex evaluation method of the ecological state of watercourses. Classical approaches of streams quality evaluation are based on hydrochemical and hydrobiological methods. These methods are not replaceable in the case of determining the pollution degree of surface waters. Their joint negative attribute is concentration on watercourse bed. These methods obviously provide indirect information also on processes taking place within the whole basin. Quality of surface waters is also closely connected with hydromorphological characteristics of watercourse beds, especially with the degree of anthropogenic modifications, the character of riparian belt along streams, the sediment and runoff regime, and land use.

Since the end of the nineties of the twentieth century, tendencies to form new complex analyses have increased which would reflect the total, so called ecological, or ecohydrological condition of streams.

Complex ecohydrological methods are of principal significance when evaluating the state of water ecosystems and they give decisive information for their restoration. The ecohydrological state of a stream is determined by a set of hydromorphological characteristics of the river channel, of its runoff and suspended sediment load regime, by hydrochemical properties of surface water and by hydrobiological conditions in the stream channel, by the character of bank and riparian belts along streams, by anthropogenic transformation of its floodplain. It is indirectly influenced by physicalgeographical and social-economic conditions of the whole basin. 
The new European Water Framework Directive (2000/60/EC) underlines the significance of ecohydrological methods. Watercourses are evaluated according to an ecological statute, which is determined by biological, hydromorphological and physical-chemical parameters. The Water Framework Directive is aimed both at the state of the streambed and at its riparian belt. The ecological state of water ecosystems is classified in the Directive by three degrees: high, good and fair. Individual degrees are described only in a general way, as it is problematic to specify and to quantify the properties of ecosystems in different regions of Europe. For that purpose, evaluation procedures and water streams typologies are elaborated in different countries.

\section{Aims and methods}

The aim of this research was to elaborate a method fitted for ecohydrological monitoring of small streams and its verification and application on the model study area. It includes analyses of the existing evaluation ecohydrological approaches. Principal for elaboration of these method were also studies on fluvial-morphological characteristics of natural or near-natural streams.

The great majority of existing evaluation approaches concern watercourses of higher orders according to the classification by Strahler (Strahler 1957). For instance the LAWA method (DWVK, LAWA 1996) was created for the needs of area evaluation and mutual comparison of ecological structures of water streams in the whole Germany. It is extended by the BfG Koblenz method (LAWA 1998), formulated and used within the Elbe (Labe) project in pilot segments of the Elbe (Labe) River in Germany and in the Czech Republic. This method is used for evaluation of ecological state of so-called significant watercourses with a channel larger than $10 \mathrm{~m}$. Another of the methods, "Ecological evaluation streams" by Niehoff (1996), was also created for middle to large basins.

Ecological principles of evaluation are also discussed in the study "A Guide to HABSCORE Field Survey Methods and the Completion of Standard Forms" (NRA 1995). The HABSCORE system was elaborated as a tool for evaluation of watercourses state from the viewpoint of protection of salmon streams. Method "River Habitat Survey" (NRA 1992, 1995) was created on the basis of the evaluation "River Corridors Survey" (NRA 1992, 1995). This method covers a complex of evaluation parameters, e.g. fluvial-morphological characteristics of stream bed and stream banks, a flow type, character of stream bank vegetation and of riparian zone, land use in the riparian belt in $50 \mathrm{~m}$ along the stream, but the evaluation system was not elaborated.

Several studies based on ecological principles have been elaborated in the USA and Canada. For example - evaluation of river habitat ecosystems "Rapid Bioassesment Protocols For Use in Streams and Wadeable Rivers" (Barbour 1999), which is a part of the complex biological monitoring of rivers. This method is used as a national standard for ecological evaluation of watercourses.

In the Czech Republic only a few ecohydrological studies have been published. A study concerned with multicriterial analysis of watercourses was elaborated by Šindlar (Šindlar 1998) and used for the needs of the Ministry of the Environment of the Czech Republic - Water Ecosystems Restoration 
Programme. An applied ecological study was preceded within the project on the Bilina river basin (Havlík et al. 1997).

\section{Ecomorphological evaluation of the stream habitat}

Only little attention has been up to now paid to small streams. For the reason of absence of suitable method for small streams, within the framework of the research project GAUK "Water Quality Research in the Berounka River Basin" (Langhammer, Matoušková 1999) and work on Ph.D. Thesis "Ecohydrological monitoring as a basis for restoration of streams" (Matoušková 2003) the method of ecomorphological evaluation of stream habitat quality was elaborated.

This method is an instrument for evaluation of stream ecomorphological state in free countryside as well as in urban areas. It is based on a combination of field investigation, processing of available data and maps. The water ecosystem is understood here as a larger territory, which is formed by individual mutually interconnected zones. It is therefore not bound only to the riverbed. The unit of the highest order is the basin, and then there are delimited zones of the flood plain, of riparian belts and of the stream channel.

The method of ecomorphological monitoring is composed of several separate evaluated parameters that get mutually integrated during the evaluation. It includes the analysis of fluvial-morphological features of the channel, of the anthropogenic transformation of the hydrographical network, of the quality of surface water, of the state of bank vegetation, of the land use in riparian belt and of selected ecohydrological features of the basin (Tab 1). The ecomorphological evaluation is based on the so-called "potential natural state" which is the state of the stream that is formed during the given physical-geographical development of the given area without significant negative anthropogenic impacts in the landscape. Nevertheless, it is not the "historical" state of the stream in the untouched natural landscape.

Ecomorphological mapping is done in determined segments, which are homogenous or heterogeneous in dependence on the size of the basin. In the case of small watercourses (catchments area $<100 \mathrm{~km}^{2}$ ), it is suitable to perform the mapping in segments of constant length. The recommended segment length is $100 \mathrm{~m}$ or $200 \mathrm{~m}$ depending on the accuracy, requirements, and purpose of the mapping. In the case of larger basins (catchments area $>100$ and $<500 \mathrm{~km}^{2}$ ), it is suitable to perform the ecomorphological mapping in segments of varying length, with the emphasis laid on their qualitative homogeneity. Length of individual segments lies within the range of 500-1000 m. Each segment of the watercourse is delimited exactly on the map and marked numerically. Their mutual non-overlapping must be guaranteed. For the field mapping, spring and autumn periods are favourable. Investigation of hydromorphological structures of the bed should be performed during low flow. Mapping results are recorded in a working form of the ecomorphological evaluation, in maps, and subsequently processed to obtain their digital form, and finally evaluated using a spreadsheet editor and represented in thematic layers of GIS.

Individual parameters are classified by a score in the interval $\langle 0 ; 5\rangle$. The values of partial parameters are calculated on the basis of the worst registered value that is on the principle of maximum or on the basis of the prevailing, so-called dominating value or with the help of arithmetic average. 
Tab. 1 - Ecomorphological parameters

\begin{tabular}{|c|c|c|c|}
\hline $\begin{array}{l}\text { Ecomorphological } \\
\text { zone }\end{array}$ & $\begin{array}{l}\text { Main } \\
\text { ecomorphological } \\
\text { parameter }\end{array}$ & $\begin{array}{l}\text { Partial ecomorphological } \\
\text { parameter }\end{array}$ & $\begin{array}{l}\text { Evaluation } \\
\text { (point P / } \\
\text { verbal V) }\end{array}$ \\
\hline Stream channel & $\begin{array}{l}\text { Fluvial-morphology } \\
\text { and meandering } \\
\text { Longitudinal profile } \\
\text { Cross section profile } \\
\text { River bed } \\
\text { Bank structures } \\
\text { Water quality }\end{array}$ & $\begin{array}{l}\text { Type of river valley } \\
\text { Meandering } \\
\text { River bed (character and shape) } \\
\text { Deepening of river channel } \\
\text { Accumulation structures } \\
\text { Existence of steps } \\
\text { Channelization } \\
\text { Riffles and pools } \\
\text { Type of water flow } \\
\text { Degree of depth variability } \\
\text { Man-made changes in outflow } \\
\text { Type of cross section } \\
\text { Depth (average) } \\
\text { Degree of length variability } \\
\text { Type of river training } \\
\text { Character of substrate } \\
\text { Type of bed training } \\
\text { Substrate diversity } \\
\text { Microhabitats } \\
\text { Vegetation } \\
\text { Type of bank structures } \\
\text { Unstableness of banks } \\
\text { Hydrochemical parametres } \\
\text { Hydrobiological parametres } \\
\text { Sewage outfalls }\end{array}$ & $\begin{array}{l}\mathrm{V} \\
\mathrm{V}, \mathrm{P} \\
\mathrm{P} \\
\mathrm{P} \\
\mathrm{P} \\
\mathrm{P} \\
\mathrm{P} \\
\mathrm{P} \\
\mathrm{P} \\
\mathrm{P} \\
\mathrm{P} \\
\mathrm{P} \\
\mathrm{V} \\
\mathrm{P} \\
\mathrm{P} \\
\mathrm{V} \\
\mathrm{P} \\
\mathrm{P} \\
\mathrm{P} \\
\mathrm{P} \\
\mathrm{P} \\
\mathrm{P} \\
\mathrm{P} \\
\mathrm{P} \\
\mathrm{V}\end{array}$ \\
\hline Vegetation belt & & $\begin{array}{l}\text { Existence of riparian belt } \\
\text { Character of riparian belt } \\
\text { Retention of riparian belt }\end{array}$ & $\begin{array}{l}\mathrm{P} \\
\mathrm{P}\end{array}$ \\
\hline Flood plain & & $\begin{array}{l}\text { Land use in flood plain } \\
\text { Flood control measures } \\
\text { Retention potential of flood plain }\end{array}$ & $\begin{array}{l}\mathrm{P} \\
\mathrm{P} \\
\mathrm{P}\end{array}$ \\
\hline Water basin & & $\begin{array}{l}\text { River training } \\
\text { Susceptible to erosion } \\
\text { Land cover } \\
\text { Drainage areas } \\
\text { Retention areas }\end{array}$ & $\begin{array}{l}\mathrm{P} \\
\mathrm{P} \\
\mathrm{P} \\
\mathrm{P} \\
\mathrm{P}\end{array}$ \\
\hline
\end{tabular}

The evaluation is done on the basis of additive principle. All ecomorphological zones have the same importance for determination of the so-called ecomorphological state, which is calculated as the arithmetical average of the evaluated ecomorphological zones. The ecomorphological state is then classified on the basis of assignment of numerical result into one of the defined ecomorphological classes.

\section{The model study area}

The model area for application of the described method was the Rakovnický Brook basin, which corresponds to the requirements of anthropogenic transformation of the hydrographical network and of the stream order. At the 


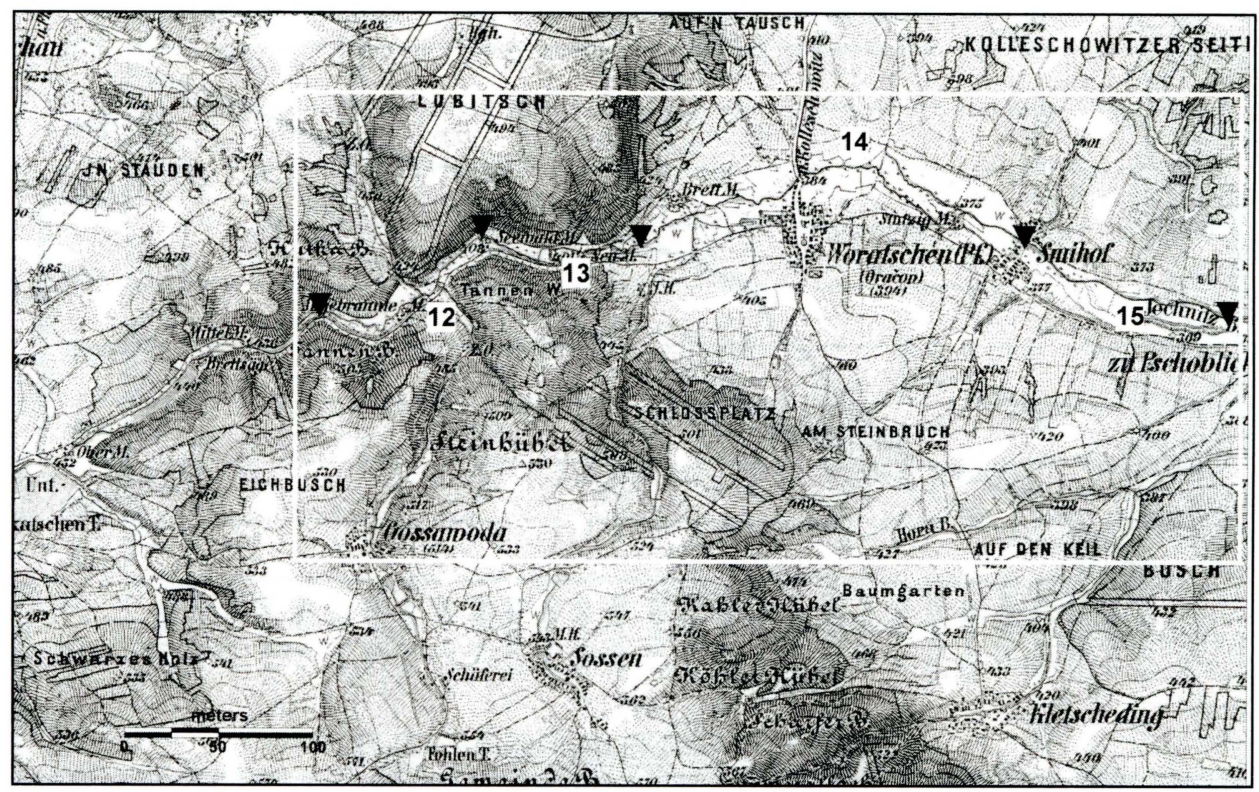

Fig. 1 - Historical map of the Rakovnický Brook. Delimitation of ecomorphological segments for comparing analysis, III. Military mapping from 1879. Source: Map collection, Charles University in Prague.

same time, a sufficient quantity of monitored input data and of other information was available for the given territory.

The Rakovnický Brook is a left affluent of the Berounka River, into which it mouths at the 63.3 river kilometre. The drainage area is 368.14 square $\mathrm{km}$ and the length of the main stream is $47.37 \mathrm{~km}$. The mean long-term discharge at the middle part (Rakovník gauging station) is $0.67 \mathrm{~m}^{3} \cdot \mathrm{s}^{-1}$, at the brook mouth then $0.86 \mathrm{~m}^{3} \cdot \mathrm{s}^{-1}$ (in the evaluated period 1970-2001). The stream passes through two geologically different units. In the north-western part prevail Permian-Carboniferous formations; Proterozoic slates and spilites dominate the south-eastern part. These geological structures condition the geomorphologic features of the relief and determine the basic features of the hydrographical network, which has been in many segments anthropogenically transformed. The stream training works has affected more than one third of the basin. Stream channels in this basin have been further transformed in connection with the flood control measures, with urbanization and sewerage system outfalls, with crossing of streams by communications, etc. The oldest stream training was done in the $14^{\text {th }}$ century when building mills and millraces, then in the $16^{\text {th }}$ and $17^{\text {th }}$ century when building a system of ponds at the upper and middle part of the Rakovnický Brook. These oldest stream-works are now conceived positively, as they are very well integrated into the landscape and give it its specific scenery (Fig. 1).

The total modification of the hydrographical network is $44.6 \%$, which is above average when compared with the national percentage of modified watercourses (28.4\% according to the Ministry of Environment $\check{C} R, 1995$ ). The straightening and shortening of streams is largely predominating, as well as deepening and stabilization of water channels mainly by quarry stones. An analysis of runoff conditions proved a dependence of changes in the runoff 


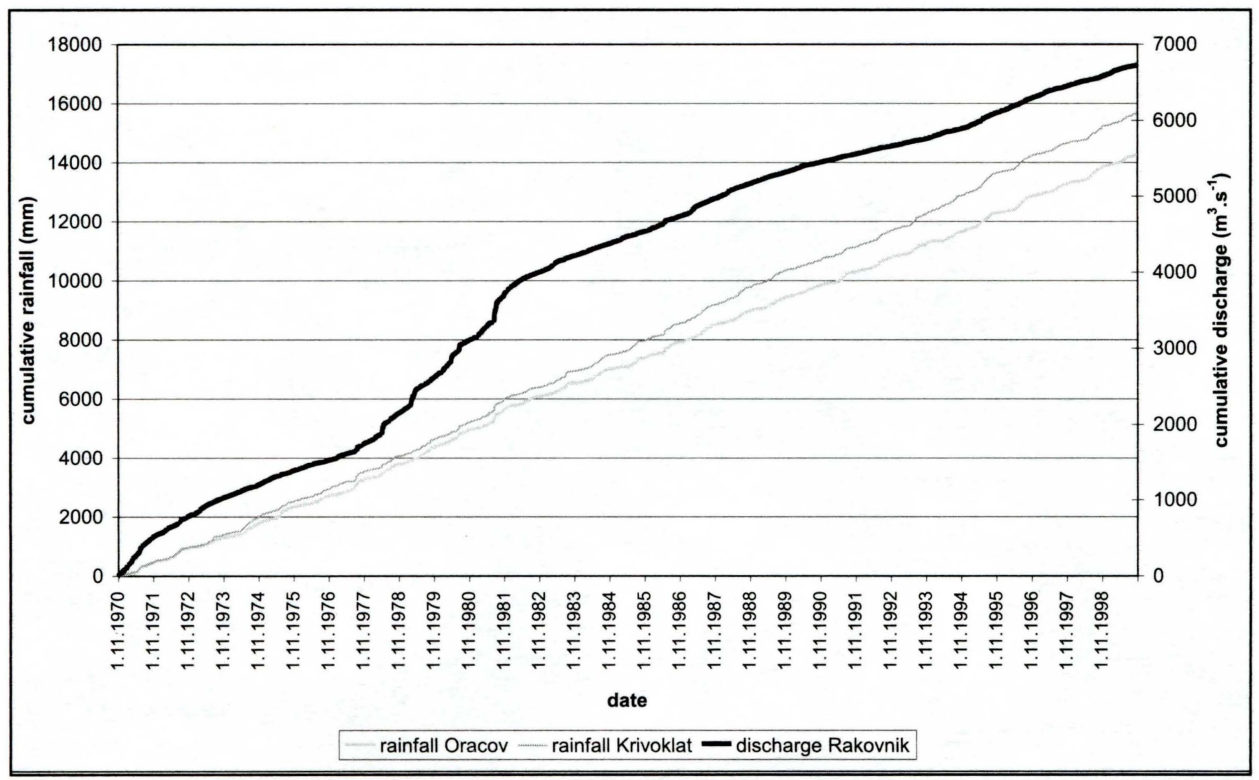

Fig. 2 - Simple mass curves of Qd and daily rainfall in the period 1970-1999. Data: ČHMÚ. The Qd mass curve proves that in the period 1978-81 there was an increased runoff, which corresponds to the period of realization of amelioration measures in the basin. The mass curve of total rainfall manifests a gradual increase in the whole monitored period 1970-1999. In the years 1990-93, there was on the contrary a decrease in the course of the Qd mass curve, which might be due to a poorer maintenance of the amelioration system. All three segments of the Qd mass curve of 1972-77, 1982-89, 1994-99 are parallel.

regime, especially its speeding-up, on the amelioration measures of the land and on training of streams (Fig. 2).

\section{Ecomorphological analysis}

Ecomorphological monitoring was done in the whole length of the main course that is in $47.37 \mathrm{~km}$. In total, 46 length heterogeneous segments were delimited. Field mapping was done in three basic zones: in the stream channel, in its riparian belts and in its floodplain. The ecomorphological state of the course and of its larger background can be characterized as anthropogenically influenced. A relatively high part $(23.4 \%)$ from the total course length represents strongly anthropogenically-influenced segments (IV th ecomorphological degree (ES, Fig. 3). This situation is alarming especially in the source region where reclamation measures have been done. The course length has been shortened; the channel was artificially lined by concrete prefabricated blocks and quarry stones. Riparian belts are insufficiently developed and cannot fulfil their protective function. In addition, fields immediately close to the stream channel are intensively cultivated. Strongly anthropogenically influenced regions include also the stream segment between Oráčov and Pšovky villages at the middle reach as well as the area in the suburb and in the agglomeration of the Rakovnik town.

Only $7.7 \%$ of the total length of the Rakovnický Brook was classified as natural that is by the first ecomorphological degree. It is the area of the upper 


\section{Ecomorphological state}

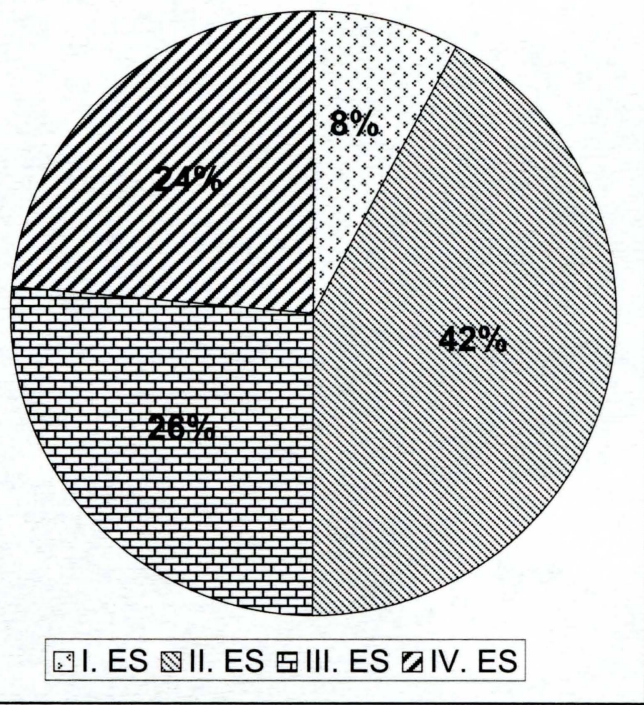

Fig. 3 - Ecomorphological state of the Rakovnický Brook. The graph shows the ecomorphological state of the Rakovnický Brook evaluated on the basis of three monitored zones: the watercourse channel, the riparian belts and the floodplain. I. ES - natural state, II. ES slightly anthropogenically influenced, III. ES anthropogenically influenced, IV. ES - strongly anthropogenically influenced. course between the Krty and Jesenice pound systems and two segments in the lower course in the Krivoklátsko Protected Landscape Area. These territories should be specially protected. Ecohydrologically significant from the protection viewpoint are also the segments classified as the second ecomorphological degree (IInd ES), that is only slightly anthropogenically influenced, which represent $42.4 \%$ of the total course length (Fig. 3). They are situated mainly in the territory of the Krivoklátsko Protected Landscape Area. Especially thanks to this significant part of the IInd ES, the model basin of the Rakovnický Brook can be characterized as intermediate anthropogenically influenced in comparison with other streams in the Czech Republic passing through a landscape with strong agricultural and industrial impacts (Fig. 4). Strongly anthropogenically influenced segments (IVth ES) are situated at the middle course of the Rakovnický

Brook in the agglomeration of the Rakovnik town (Fig. 5).

When evaluating the basin zone, regions possibly endangered by negative anthropogenic activities, especially by intensive farming on agricultural lands, were identified on the basis of intersection of individual evaluated factors that is anthropogenic transformation of the hydrographical network, the soils erosion risk, the land cover structure, and the ecological potential of soils resources. The endangered regions are situated at the upper course of the Lišanský Brook, then in the watershed of the Kolešovický Brook, in the source region of the Rakovnický Brook and of its right effluents, the Petrovický, Cerný and Jalový Brooks, and then in some partial areas in the Ryšava catchment (Fig. 6). In these regions it would be useful to take antierosion measures. Sufficiently large riparian belts should be created along watercourses.

The ecomorphological analysis makes it clear that rehabilitation of streams and of riparian belts should be oriented mainly into the spring area and middle course classified by the IVth ecomorphological degree, where the stream is passing mostly through agricultural landscape. A total renaturalisation of the course should be done there. It means above all to create sufficiently large riparian belts, to back the development of natural fluvial-morphological structures of the channel that would help to increase the bio- and geodiverzity of its habitat. It is also necessary to plant or to restore the bank and the riparian vegetation. Within individual communes 


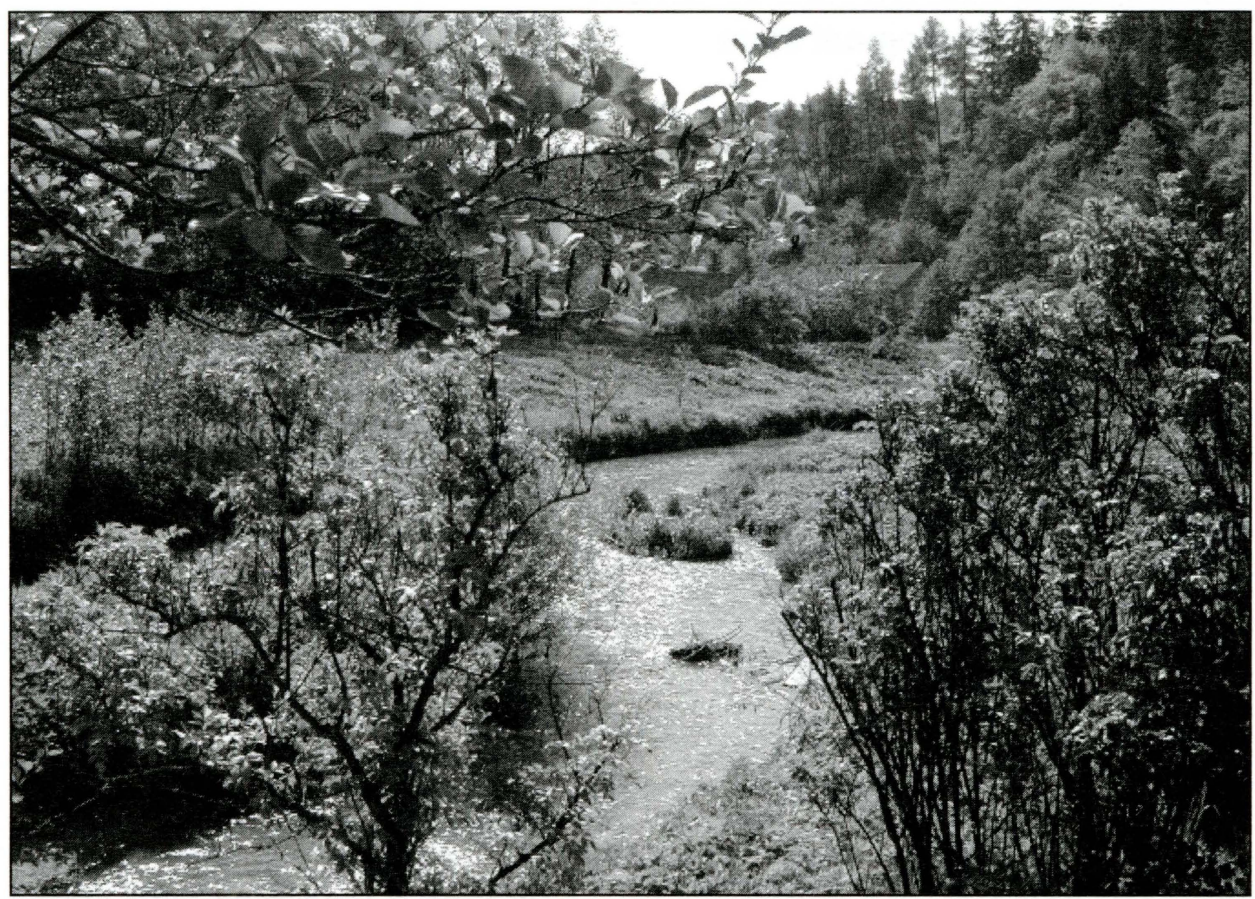

Fig. 4 - Natural part of the Rakovnický Brook in the Protected Landscape Area Křrivoklátsko.

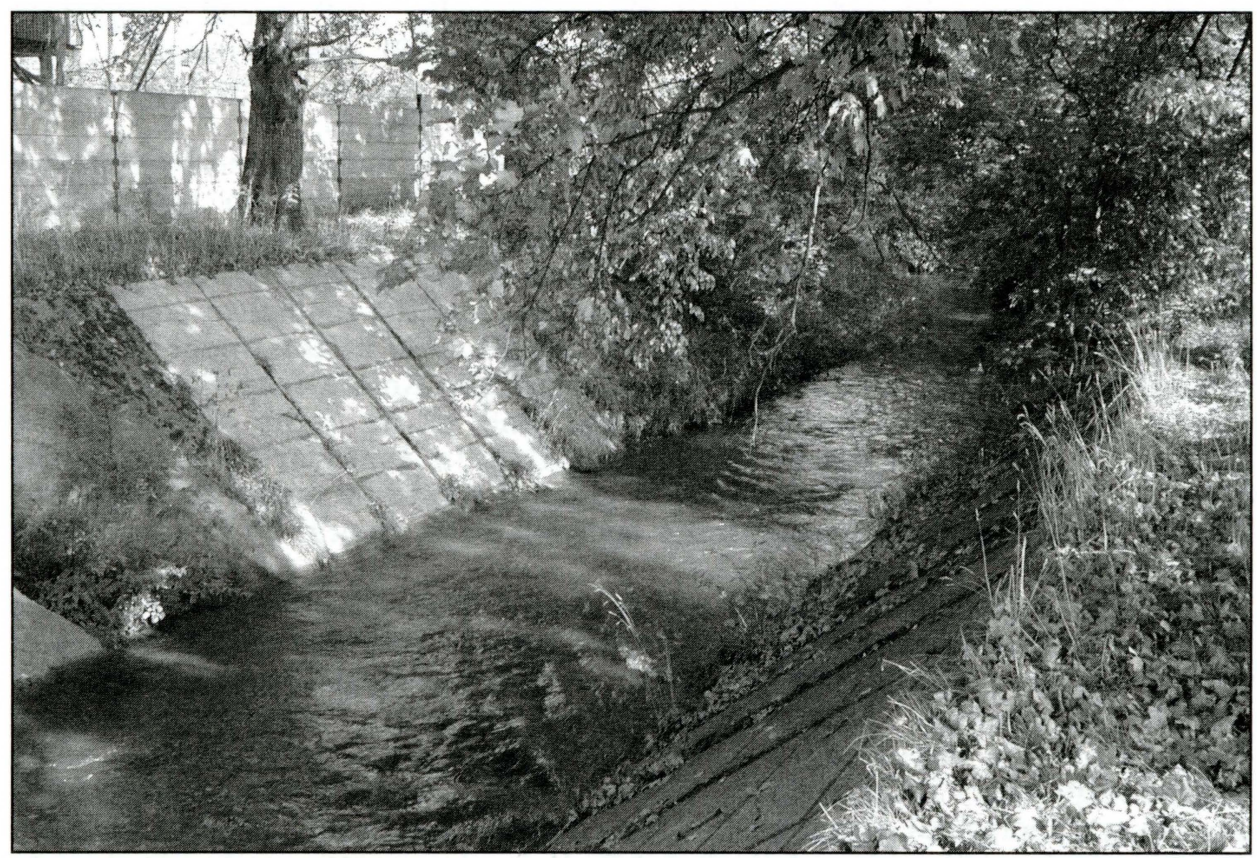

Fig. 5 - Strongly anthropogenically influenced segments (IV ${ }^{\text {th }}$ ecomorphological degree) at the middle course of the Rakovnický Brook in the agglomeration of the Rakovnik town. 


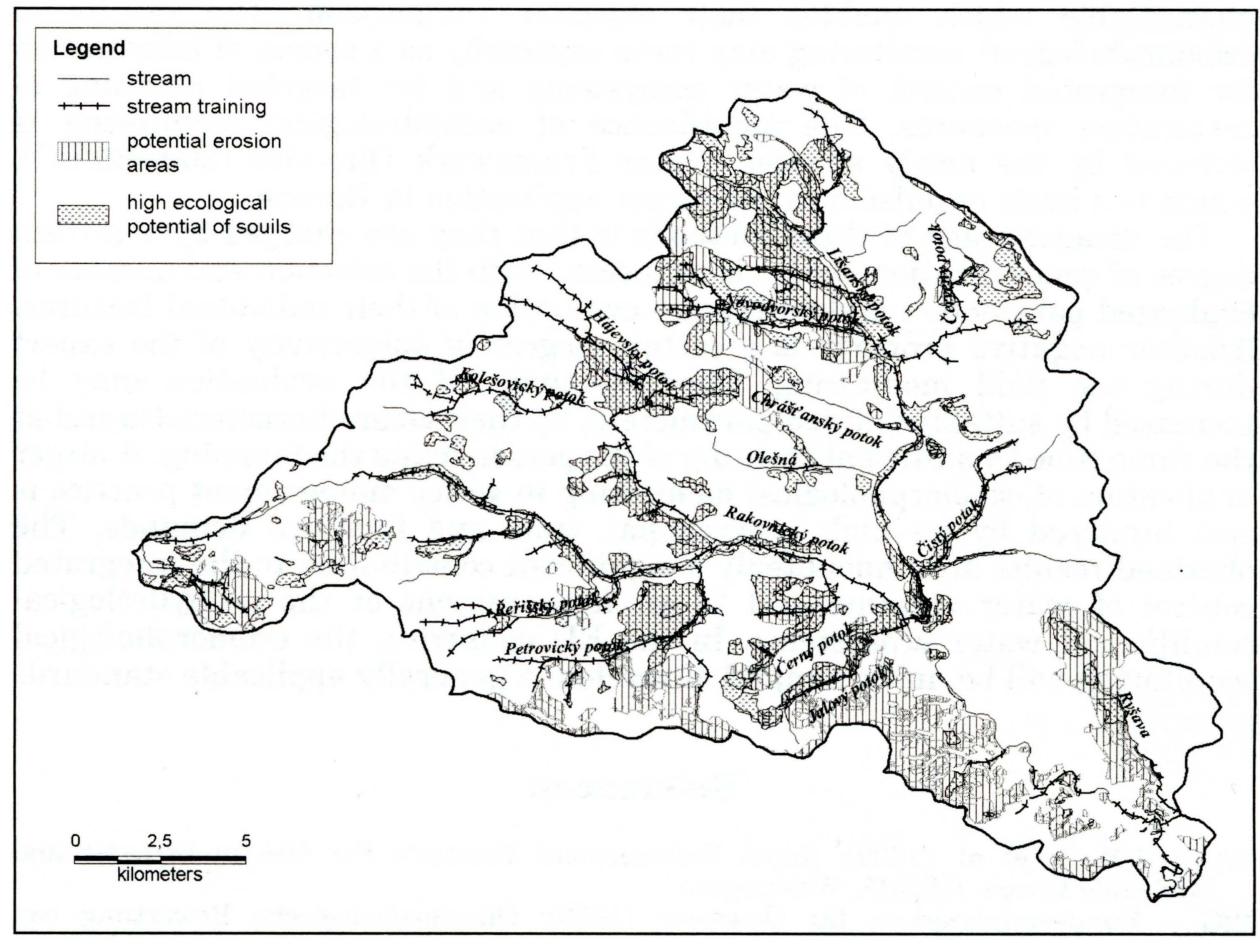

Fig. 6 - Map of the Rakovnický Brook basin. The map shows regions, which are endangered by negative anthropogenic activities, especially by transformation of the hydrological river network and high soils erosion risk.

and in the territory of the town of Rakovník, in the segments classified as the $\mathrm{IV}^{\text {th }}$ ecomorphological degree, the so-called partial restoration should be done. It means mainly to prevent an excessive pollution of the watercourse, to proceed to biotechnological modifications of the channel and to restore bank or riparian vegetation.

\section{Conclusion}

Application of the method of ecomorphological monitoring in the model basin of the Rakovnický Brook has confirmed the possibility to identify anthropogenically-influenced segments of watercourses and basin areas fitted for possible restoration measures. This method has brought good results also when used and tested in the Habrový Brook (Garkischová 2002) and the Košínský Brook basins (Bicanová 2002). Stříbrský (2002) compared in his degree work two methods - the BfG Koblenz one (LAWA 1998) and the method of eccomorphological monitoring (Matoušková 2002) on several model segments of Rakovnický Brook. The obtained outputs are similar, which documents the objectivity of the method of ecomorphological monitoring.

An incontestable advantage of the ecohydrological evaluation of water ecosystems is a complex view on streams. It is important to take into account the ecological situation of a larger background of the stream, possibly of the whole basin, as a basic hydrographical unit. The obtained outputs are mostly 
quantifiable which enables their objective comparison. The results of ecomorphological monitoring may serve especially as a source of information for integrated control of water ecosystems and for targeted planning of restoration measures. The significance of ecohydrological monitoring is stressed by the newly adopted Water Framework Directive (2000/60/EC), which is a basic impulsion for its larger application in Europe.

The disadvantage of these methods is that they are charged by a certain degree of generalization, which is connected with the selection and number of evaluated parameters and with score evaluation of their individual features. Another negative property is a certain degree of subjectivity of the expert during the field monitoring. The objectivity of the evaluation may be increased by suitably defined parameters, by their clear characteristic and at the same time by sufficient training of the person doing the mapping. A larger application of ecomorphological monitoring in water management practice is still hindered by its high professional, time and financial demands. The obtained results are undoubtedly a significant contribution to the integrated control of water streams and to an improvement of the ecohydrological condition of water ecosystems. In the EU countries, the ecomorphological monitoring will be, in its simplified version, a generally applicable standard.

\section{References:}

BARBOUR, T. et al. (1999): Rapid Bioassesment Protocols For Use in Streams and Wadeable Rivers. USEPA, Washington.

BfG - Bundesministerium für Gewässer (1998): Ökomorphologische Bewertung von Fließgewässern. BfG, Koblenz.

BICANOVÁ, M. (2002): Fyzickogeografická charakteristika povodí Košínského potoka, zhodnocení ekohydrologického stavu toku. Seminar work. Pr̆F UK, Praha.

DVWK - Deutscher Verband für Wasserwirtschaft und Kulturbau, LAWA Länderarbeitsgemeinschaft Wasser (1996): Gewässerstrukturgütekartierung in der Bundesrepublik Deutschland - Verfahrensempfehlung des DVWK, im Auftrag der LAWA. DVWK-Fachausschuß 4.13 „Bewertung von Fließgewässern“, München.

GARKISCHOVÁ, A. (2002): Ekohydrologické hodnocení v povodí Habrového potoka. Master Thesis. PřF UK, Praha.

HAVLÍK, A. et al. (1997): Ekologická studie v povodí Bíliny. Research report, No. 72, VÚV T.G.M., Praha.

KOVÁR̆, M. (2002): Studie ekomorfologického stavu toků v povodí nádrže Jordán. Master Thesis. ČVUT, Stavební fakulta, Praha.

LAWA - Länderarbeitsgemeinschaft Wasser (1998): Strukturgütekartierung in der Bundesrepublik Deutschland, LAWA, Koblenz.

LANGHAMMER, J. (2000): Výzkum kvality vodní složky přírodního prostředí v povodí Berounky. Final research report, grant project GAUK, No. 27298-B-GEO, PřF UK, Praha.

MATOUŠKOVÁ, M. (2002): Ökohydrologisches Monitoring als Grundlage für die Revitalisierung von Fliessgewässern. 10. Magdeburger Gewässerschutzseminar. Teubner, Stuttgart, pp. 206-209.

MATOUŠKOVÁ, M. (2003): Ekohydrologický monitoring jako podklad pro revitalizaci vodních toků. Ph.D. Thesis, PřF UK, Praha.

MŽP ČR (1995): Upravenost vodních toků v ČR. MŽP ČR, www.env.cz.

NRA - National River Authority (1992): River Coridors Surveys - Methods and Procedure. NRA, Bristol.

NRA - National River Authority (1995): A Guide to HABSCORE Field Survey Methods and the Completion of Standard Forms, Bristol.

NRA - National River Authority (1995): Field Methodology Guidance Manual. NRA, Bristol.

NIEHOFF, N. (1996): Ökologische Bewertung von Fließgewässerlandschaften. Grundlage für Renaturierung und Sanierung. Springer Verlag, Berlin, Heidelberg. 
STRAHLER, A., N. (1957): Quantitative analysis of watershed geomorphology. Transactions of the America Geophysical Union, $38 \mathrm{p}$.

STŘÍBRSKÝ, M. (2002): Ekomorfologické hodnocení malých vodních toků. Master Thesis. ČVUT, Stavební fakulta, Praha.

ŚINDLAR, M. (1998): Dynamika a ochrana přirozených ekosystémů vodních toků. Final research report, project DÚ 01-A. MŽP ČR, Praha.

WFD (Water Framework Directive) 2000/60/EC of the European Parliament and of the Council of 23 October 2000 (2000): Official Journal of the European Communities, I., 327, No. 1. Luxemburg.

\section{Shrnutí}

\section{EKOHYDROLOGICKÝ MONITORING KVALITY PŘIROZENÉHO PROSTŘEDÍ ŘEK}

Ekohydrologický monitoring je novým nástrojem pro hodnocení stavu vodních toků. Získané výstupy poskytují rozhodující informace pro integrovanou ochranu vodních tokủ a jejich revitalizaci. Ekohydrologický stav vodního toku je určen souborem hydromorfologických charakteristik koryta, odtokovým a splaveninovým režimem, hydrochemickými vlastnostmi vodního média a hydrobiologickými poměry v korytě toku, charakterem břehových a doprovodných vegetačních pásů podél vodních toků, antropogenní transformací údolní nivy. Nepřímo je ovlivněn fyzickogeografickými a socioekonomickými poměry celého povodí.

Převážná většina hodnotících přístupů se věnuje vodním tokům vyšších řádů podle Strahlerovy klasifikace. Nově formulovaná metoda ekomorfologického monitoringu drobných vodních toků je nástrojem pro ekohydrologické hodnocení v intra- a extravilánech. Je založena na kombinaci terénního průzkumu a zpracování distančních dat. Vodní ekosystém je zde chápán jako širší území, které je tvořeno jednotlivými vzájemně propojenými zónami. Prostorovou jednotkou nejvyššího řádu je povodí a dále jsou vymezeny zóny údolní nivy, doprovodných vegetačních pásủ a koryta vodního toku. Tato metoda zahrnuje analýzu fluviálně-morfologických charakteristik koryta, antropogenní transformace hydrografické sítě, jakosti povrchové vody, stavu břehové vegetace, využití ploch podél vodních toků a vybraných ekohydrologických charakteristik povodí.

Modelovým povodím pro aplikaci dané metody bylo zvoleno povodí Rakovnického potoka, které splňuje vstupní požadavky týkající se antropogenní transformace hydrografické sítě, velikostního řádu povodí a zároveň dostatečného množství vstupních dat. Ekomorfologický stav Rakovnického potoka a jeho přípřežní zóny je možno označit za antropogenně ovlivněný. Relativně vysoký podíl $(23,4 \%)$ z celkové délky toku zaujímají silně antropogenně ovlivněné úseky (IV. ekomorfologický stupeň, ES). Tento stav je již znepokojivý v pramenné oblasti, kde došlo $\mathrm{k}$ melioračním úpravám hydrografické sítě. $\mathrm{K}$ silně antropogenně ovlivněným oblastem náleží i střední tok Rakovnického potoka. Pouhých $7,7 \%$ z celkové délky toku bylo klasifikováno jako př́rodní, tj. I. ES. Jedná se o oblast horního toku mezi Krtskou a Jesenickou rybniční soustavou a o úseky v CHKO Křivoklátsko. Tato území by měla být předmětem zvláštní ochrany. V rámci hodnocení zóny povodí byly identifikovány oblasti potenciálně ohrožené vůči negativním antropogenním činnostem, především intenzivnímu obhospodařování zemědělských ploch.

Metoda ekomorfologického monitoringu přinesla rovněž dobré výsledky při její aplikaci v několika dalších modelových povodích při řešení diplomových prací na PřF UK v Praze a ČVUT v Praze (Bicanová 2002, Garkischová 2002, Kovář 2002, Stř́íbrský 2002).

Výsledky ekomorfologického monitoringu mohou sloužit zejména jako zdroj informací pro integrovanou ochranu vodních ekosystémů a pro cílené plánování revitalizačních opatření v krajině.Význam ekohydrologického monitoringu zdůrazňuje nově přijatá Rámcová směrnice ochrany vod (2000/60/EC), která je základním podnětem pro jeho širší aplikaci v Evropě.

Obr. 1 - Historická mapa Rakovnického potoka. Vymezení ekomorfologických úseků pro porovnávací analýzu, III. Vojenské mapování z roku 1879. Zdroj: Mapová sbírka, Univerzita Karlova v Praze.

Obr. 2 - Jednoduché součtové čáry Qd a denních srážek v období 1970-1999. Data: ČHMÚ. Součtová čára Qd prokazuje, že v období 1978-81 došlo ke zvýšenému nárůstu odtoku, což odpovídá době, kdy byly realizovány hydromeliorační opatření v povodí. Součtové čáry srážkových úhrnů vykazují v celém monitorovaném období 
1970-1999 pozvolný nárůst. V letech 1990-93 došlo k naopak poklesu v průběhu součtové čáry, což může souviset s omezením údržby meliorací. Všechny tři segmenty součtové čáry průtoků 1972-77, 1982-89, 1994-99 jsou rovnoběžné.

Obr. 3 - Ekomorfologický stav Rakovnického potoka. Graf znázorňuje celkový ekomorfologický stav Rakovnického potoka vyhodnocený na základě třech monitorovaných zón: koryta vodního toku, doprovodných vegetačních pásů a údolní nivy. I. ES přírodní stav, II. ES - mírně antropogenně ovlivněný, III. ES - středně antropogenně ovlivněný, IV. ES - silně antropogenně ovlivněný.

Obr. 4 - Přírodní úsek Rakovnického potoka na území Chráněné krajinné oblasti Křivoklátsko.

Obr. 5 - Silně antropogenně ovlivněné úseky (IV. ekomorfologický stupeň na středním toku Rakovnického potoka v intravilánu města Rakovníka.

Obr. 6 - Mapa znázorňuje oblasti potenciálně ohrožené negativní antropogenní činností, především na základě antropogenní transformace hydrografické sítě a erozního ohrožení půd.

(Author is with Charles University in Prague, Faculty of Science, Department of Physical Geography and Geoecology, Albertov 6, 12843 Praha 2, Czechia;

e-mail: matouskova@natur.cuni.cz.) 